\title{
Penyediaan format isian berbasis komputer untuk pencatatan pendistribusian bahan bakar minyak bersubsidi di SPBU-N Koperasi Perikanan Pantai Madani Kabupaten Bengkalis
}

\author{
Miswadi $^{1}$, Romie Jhonnerie ${ }^{2}$, dan Yossi Oktorini ${ }^{3}$ \\ ${ }^{1}$ Mangrove Research Institute \\ ${ }^{2}$ Jurusan Pemanfaatan Sumberdaya Periakanan, Fakultas Perikanan dan Kelautan, Universitas Riau \\ ${ }^{3}$ Jurusan Kehutanan, Fakultas Pertanian, Universitas Riau \\ * miswapratama@gmail.com
}

\begin{abstract}
Abstrak. Koperasi Perikanan Pantai Madani adalah pengelola stasiun pengisian bahan bakar umum untuk nelayan (SPBU-N) yang mendistribusikan bahan bakar minyak solar bersubsidi untuk usaha penangkapan ikan di wilayah Desa Pambang Pesisir dan sekitarnya. Pencatatan penjualan bahan bakar minyak tersebut selama ini masih dilakukan secara manual dengan kalkulator sebagai alat bantu hitung dan terjadi penghitungan ulang untuk mendapatkan informasi untuk kebutuhan laporan bulanan dan tahunan. Pemberdayaan pengelola SPBU-N untuk menggunakan format isian berbasis komputer dalam bentuk tabulasi bertujuan untuk memberikan kemudahan bagi pengelola SPBU-N dalam memperoleh informasi mengenai rekapitulasi perkembangan pendistribusian bahan bakar minyak bersubsidi sehingga penyampaian laporan stok harian, bulanan dan tahunan kepada PT (Persero) Pertamina dapat dilakukan tepat waktu. Kegiatan ini menggunakan metode presentasi, bimbingan teknis dan monitoring. Hasil kegiatan ini berupa tersedianya format isian yang telah lakukan langsung dari data riil penjualan SPBU-N tahun 2014-2018. Pengelola SPBU-N telah menggunakan format isian tersebut untuk melakukan pencatatan terhadap pendistribusian bahan bakar minyak bersubsidi untuk tahun 2019. Format isian tersebut memudahkan pihak pengelola SPBU-N untuk memperoleh informasi yang dibutuhkan untuk pelaporan karena pencatatan harian telah terintegrasi dengan kebutuhan informasi laporan bulanan dan tahunan..
\end{abstract}

Kata kunci: BBM bersubsidi; pambang pesisir; format berbasis komputer; KPPM; SPBU-N

\begin{abstract}
The cooperative of Perikanan Pantai Madani is the institution of a public refueling station for fishermen (SPBU-N) who distributes subsidized diesel fuel for fishing activities in the Pambang Pesisir Village and surrounding areas. All purchases transactions were implemented manually and used common counting tool and recounts occur to retrieve information for the needs of monthly and annual reports. This empowerment aimed to provide convenienced for SPBU-N manager due to gain information for recapitulation of subsidized fuel distribution, and the daily (monthly) and annual stock reports to PT Pertamina can be delivered on time, confidently. The mothods used were presentation, technical guidance and monitoring. The result of these activities were the availability of a standard form which developed from real transaction data (2014-2018). The SPBU-N manager has used the form provided and recorded the distribution of subsidized fuel oil for 2019, which made easier for the manager obtained the information needed for reporting since daily records have been integrated with the monthly and annual report information needs.
\end{abstract}

Keywords: subsidized fuels; pambang pesisir; computerized form; KPPM; SPBU-N

To cite this article: Miswadi, R. Jhonnerie, \& Y. Oktorini. 2019. Penyediaan format isian berbasis komputer untuk pencatatan pendistribusian bahan bakar minyak bersubsidi di SPBU-N Koperasi Perikanan Pantai Madani Kabupaten Bengkalis. Unri Conference Series: Community Engagement 1: 130-138.

https://doi.org/10.31258/unricsce.1.130-138

(C) 2019 Authors

Peer-review under responsibility of the organizing committee of Seminar Nasional Pemberdayaan Masyarakat 2019 


\section{PENDAHULUAN}

Koperasi Perikanan Pantai Madani (KPPM) merupakan salah satu koperasi di Kabupaten Bengkalis yang mengelola Stasiun Pengisian Bahan Bakar Umum untuk Nelayan (SPBU-N). SPBU-N merupakan unit perpanjangan pelayanan PT (Persero) Pertamina dalam pengadaan bahan bakar minyak bagi masyarakat nelayan. Bahan bakar minyak yang disediakan adalah bahan bakar minyak (BBM) bersubsidi jenis solar untuk keperluan kapal motor nelayan (ukuran <30 GT) dalam melakukan usaha penangkapan ikan (KKP, 2015). Usaha distribusi BBM bersubsidi di Koperasi Perikanan Pantai Madani telah dimulai sejak tahun 2002 dalam bentuk usaha dagang eceran khusus untuk nelayan (YLS, 2003) dan mulai tahun 2012 ditunjuk sebagai pengelola Solar Packet Dealer Nelayan (SPDN) (KPPM, 2013). Koperasi mulai melakukan uji coba operasional SPDN pada bulan Januari tahun 2014 dan resmi beroperasi pada bulan Juli tahun 2014 sehingga data penjualan resmi SPDN dimulai tahun 2014 dan SPDN teregistrasi dengan nomor 19.288.002 di PT (Persero) Pertamina (KPPM, 2015). Sejak tahun 2017, SPDN berubah nama menjadi SPBU-N Tipe A dengan nomor registrasi 18.288.066 (KPPM, 2018).

Salah satu kewajiban pengelola SPBU-N bahan bakar minyak (BBM) bersubsidi adalah menyampaikan laporan pendistribusian BBM bersubsidi kepada PT (Persero) Pertamina dalam bentuk laporan harian, bulanan dan tahunan. Penyampaian laporan pendistribusian BBM bersubsidi ini dilakukan dengan memanfaatkan jarngan internet sehingga kemampuan sumber daya manusia koperasi tidak hanya dituntut mahir dalam mengelola usaha, namun juga dalam memanfaatkan teknologi kekinian seperti komputer dan telepon pintar (smart phone) untuk mendukung kemajuan usaha koperasi. Hal ini berimplikasi terhadap sumber daya manusia pengelola SPBU-N, dimana manajer usaha hanya memiliki kemampuan dalam mengelola usaha tetapi belum didukung dengan kemampuan memanfaatkan teknologi terkini, sehingga koperasi harus memberdayakan tenaga administrasi koperasi untuk menangani penyusunan rekapitulasi dan pelaporan pendistribusian BBM berbasis komputer. Mekanisme penyampaian laporan yang dilakukan koperasi saat ini diilustrasikan pada Gambar 1.

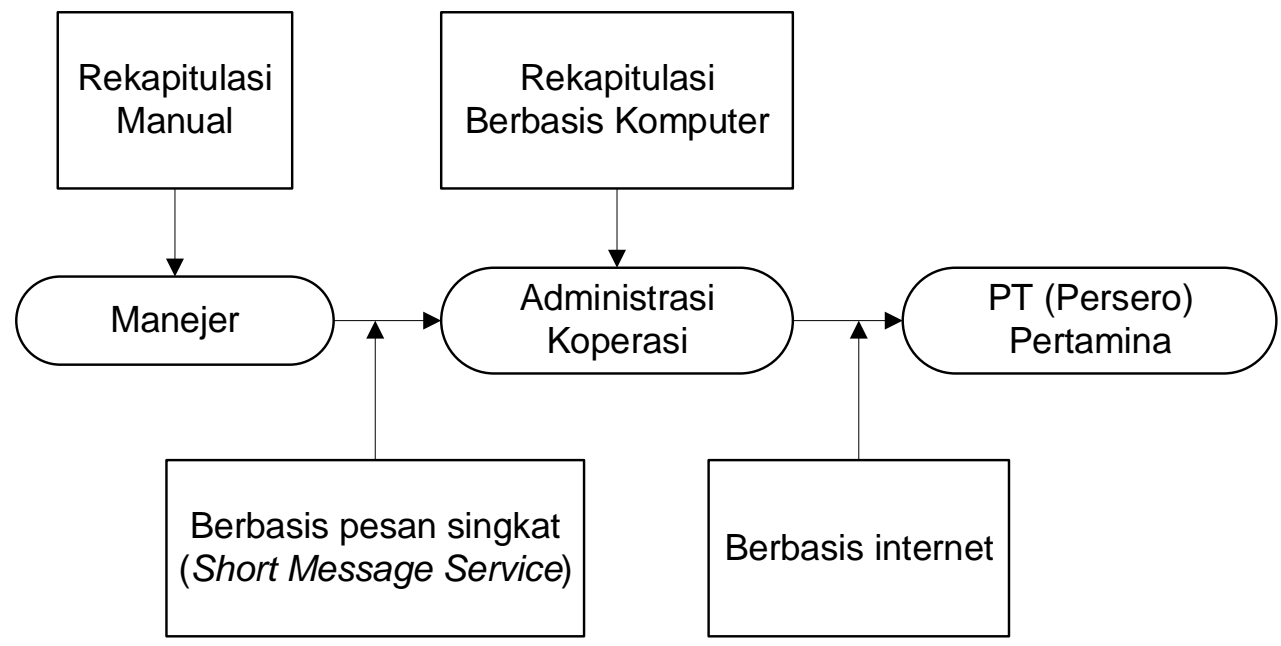

Gambar 1. Mekanisme penyampaian laporan pendistribusin BBM bersubsidi di SPBU-N Koperasi Perikanan Pantai Madani

Selama ini, koperasi melakukan pencatatan atas transaksi penjualan minyak berupa pencatatan manual dalam buku harian penjualan dan penghitungan jumlah penjualannya menggunakan alat bantu kalkulator. Pencatatan oleh Manajer SPBU-N sebagai pengelola unit usaha. Data bersumber dari nota penjualan harian dan slip penerimaan BBM bersubsidi yang dicatat pada buku penjualan SPBU-N. Rekapitulasi atas penjualan dan penerimaan BBM tersebut dilakukan rutin secara harian untuk mendapatkan informasi jumlah penjualan harian, penerimaan BBM dan stok akhir. Setiap harinya, manajer menyampaikan catatan penjualan kepada tenaga administrasi koperasi melalui layanan pesan singkat (short message service/SMS) telepon seluler sebagai laporan ke PT (Persero) Pertamina.

Pada awalnya, penyampaian laporan ini hanya dalam bentuk laporan resmi tertulis yang disampaikan secara bulanan dan tahunan dengan format baku pelaporan yang ditetapkan PT (Persero) Pertamina Kantor Pemasaran Pekanbaru. Kemudian, PT (Persero) Pertamina melalui Kantor Pemasaran Pekanbaru menyampaikan himbauan bahwa laporan perkembangan pendistribusian BBM bersubsidi harus disampaikan dalam bentuk laporan harian, bulanan dan tahunan yang disampaikan menggunakan layanan pesan singkat (Short Message 
Service/SMS) telepon seluler ke pihak PT (Persero) Pertamina Kantor Pemasaran Pekanbaru. Berkembangnya aplikasi WhatsApp dalam telepon pintar telah memudahkan komunikasi bagi daerah yang telah memiliki jaringan internet sehingga penyampaian laporan perkembangan pendistribusian BBM bersubsidi juga dikembangkan dengan menggunakan aplikasi WhatsApp. Sejak tahun 2017, SPBU-N harus menyampaikan perkembangan pendistribusian BBM bersubsidi ke pihak PT (Persero) Pertamina melalui halaman resmi di website yang dikembangkan oleh PT (Persero) Pertamina untuk laporan stok harian, bulanan dan tahunan. Informasi yang disampaikan adalah rekapitulasi berupa kondisi stok awal, penjualan, penerimaan dan stok akhir BBM. Namun demikian penyampaian laporan resmi tertulis secara bulanan dan tahunan tetap diberlakukan.

Hasil rekapitulasi pendistribusian BBM bersubsidi dari pencatatan manual yang dilakukan oleh manajer unit setiap harinya selalu terjadi penghitungan ulang untuk penyampaian laporan bulanan dan tahunan karena pencatatan yang dilakukan masih menggunakan pencatatan tertulis dalam buku harian penjualan dan untuk memperoleh hasil rekapitulasi menggunakan alat bantu kalkulator. Hasil rekapitulasi ini disampaikan ke tenaga administrasi koperasi melalui layanan pesan singkat (short message service/SMS) telepon seluler untuk diteruskan menjadi laporan ke pihak PT (Persero) Pertamina. Tenaga administrasi koperasi sangat berperan penting dalam pelaporan pendistribusian BBM bersubsidi di SPBU-N dan perlu ditingkatkan kapasitas kemampuannya dalam menyusun rekapitulasi perkembangan pendistribusian BBM tersebut. Untuk itu, pencatatan pendistribusian BBM bersubsidi berbasis komputer penting dilakukan dengan tujuan agar memudahkan dalam memperoleh informasi perkembangan pendistribusian BBM bersubsidi harian, bulanan dan tahunan dengan tidak melakukan penghitungan ulang atas data penjualan yang telah dibuat. Hasil penyusunan rekapitulasi yang tepat dan informatif dapat memudahkan untuk penyampaian pelaporan kepada PT (Persero) Pertamina yang aktual dan tepat waktu.

\section{METODE PENERAPAN}

Pemberdayaan koperasi melalui peningkatan kemampuan pengelola dalam pencatatan pendistribusian BBM bersubsidi menggunakan format isian berbasis komputer dalam bentuk tabulasi telah dilakukan di SPBU-N Tipe A Koperasi Perikanan Pantai Madani yang berdomisili di Desa Pambang Pesisir Kecamatan Bantan Kabupaten Bengkalis Provinsi Riau. Kegiatan ini dilaksanakan selama 3 (tiga) bulan dari tanggal 11 November 2018 hingga 11 Februari 2019. Data dikumpulkan dengan teknik survei terhadap catatan manual pendistribusian BBM bersubsidi di SPBU-N untuk tahun buku 2014 - 2018 dan dianalisis secara deskriptif.

Hasil analisis dilanjutkan dengan menyusun format isian berbentuk tabulasi dalam format Microsoft Office Excel 2007 yang informatif untuk data stok awal persediaan, penjualan, penerimaan persediaan dan stok akhir persediaan BBM bersubsidi. Metode yang dilakukan untuk membantu pengelola SPBU-N dalam penyediaan informasi rekapitulasi pendistribusian $\mathrm{BBM}$ bersubsidi adalah dengan menyediakan format isian pendistribusian BBM bersubsidi berbasis komputer dalam format Microsoft Office Excel 2007. Kegiatan ini dilakukan dengan teknik: (1) Presentasi yang dilakukan dengan menjelaskan dan memberikan pemahaman kepada pengelola SPBU-N tentang pentingnya format isian pendistribusian BBM bersubsidi berbasis komputer; (2) Bimbingan teknis yang dilakukan dengan cara membimbing tenaga administrasi koperasi untuk melakukan input data pendistribusian BBM bersubsidi untuk tahun buku 2014 - 2018 pada format isian berbasis komputer; dan (3) Monitoring yaitu dengan melakukan monitoring terhadap tenaga administrasi koperasi dalam menggunakan format isian pendistribusian BBM bersubsidi berbasis komputer untuk tahun 2019.

\section{HASIL DAN KETERCAPAIAN SASARAN}

Komputer merupakan alat bantu yang umum digunakan saat ini terutama untuk membuat basis data dan mengolah data. Berbagai perhitungan yang sulit dipecahkan secara analitik dapat diselesaikan secara numerik dengan bantuan program komputer yang salah satu diantaranya adalah Microsof Office Excel (Sumardi, 2002). Hidayat et al. (2017) menyatakan bahwa Microsoft Office Excel adalah General Purpose Electronic Spreadsheet yang dapat digunakan untuk mengorganisir, menghitung, menyediakan maupun menganalisis data dan mempresentasikannya ke dalam bentuk grafik ataupun diagram. Saat program Microsoft Office Excel dibuka maka sebuah buku kerja (workbook) siap digunakan yang didalamnya terdapat beberapa lembar kerja (worksheet). Lembar keja dalam satu sheet terdiri dari kolom (columns) yang dilambangkan dalam tanda huruf A, B, C dan baris (rows) yang dilambangkan dalam bentuk angka 1, 2, 3. Perpotongan antara baris dan kolom disebut sel (cell). 
Format isian pendistribusian BBM bersubsidi berbasis komputer dibuat dengan mempertimbangkan kebutuhan akan informasi untuk pelaporan harian, bulanan dan tahunan pendistribusian BBM bersubsidi pada PT (Persero) Pertamina yang meliputi: kondisi stok awal, penerimaan, penjualan dan kondisi stok akhir pendistribusian BBM bersubsidi di SPBU-N Koperasi Perikanan Pantai Madani. Format isian ini disediakan dalam 1 file aplikasi spreadsheet Microsoft Office Excel 2007 untuk pencatatan selama satu tahun dan untuk tahun berbeda dibuat file yang berbeda. Setiap file berisi 13 worksheet, terdiri dari worksheet 1 sampai worksheet 12 adalah pencatatan bulanan (Januari hingga Desember) dan worksheet 13 adalah rekapitulasi tahunan. Fungsi-fungsi penting dalam Microsoft Office Excel 2007 yang digunakan untuk membuat format isian ini adalah fungsi formula dasar (Hidayat et al., 2017), meliputi: (1) fungsi tautan (link), (2) fungsi penjumlahan, (3) fungsi pengurangan dan (4) fungsi penjumlahan keseluruhan (SUM). Setiap penggunaan formula dasar harus diawali dengan tanda sama dengan $(=)$.

Format isian worksheet bulanan dibuat dengan struktur tabel data series per hari dan dilengkapi dengan tabel turunan berupa rekapitulasi bulanan pendistribusian BBM bersubsidi yang merupakan output data bulanan dan tersaji secara otomatis menggunakan fungsi tautan dari tabel data series per hari. Uraian format tabel data bulanan dengan data series per hari disajikan pada Tabel 1.

Tabel 1. Uraian format worksheet bulanan dilengkapi baris akhir tutup buku berupa total penerimaan dan total penjualan

\begin{tabular}{|c|c|}
\hline Jenis Kolom & Deskripsi \\
\hline No & Nomor urut sesuai tanggal, include \\
\hline Tanggal & Tanggal awal hingga tanggal akhir setiap bulan sesuai kalender, include \\
\hline Kuota DO & $\begin{array}{l}\text { Perkembangan kuota deposit order (DO) BBM } \\
\text { Baris } 1 \text { entry manual, sesuai DO dari PT (Persero) Pertamina } \\
\text { Baris } 2 \text { hingga akhir otomatis } \\
\text { Contoh: } \\
\text { Baris } 2 \text { Kolom Kuota DO = Baris } 1 \text { Kolom Kuota DO - Baris } 1 \text { Kolom Penerimaan }\end{array}$ \\
\hline Penj H-1 & $\begin{array}{l}\text { Penjualan BBM satu hari sebelumnya } \\
\text { Baris } 1 \text { entry manual khusus bulan Januari, sedangkan untuk bulan Februari sampai Desember } \\
\text { adalah otomatis dari baris akhir kolom penjualan bulan sebelumnya } \\
\text { Baris } 2 \text { hingga akhir otomatis } \\
\text { Contoh: } \\
\text { Baris } 2 \text { Kolom Penj H-1 = Baris } 1 \text { Kolom Penjualan }\end{array}$ \\
\hline Stok Awal & $\begin{array}{l}\text { Stok BBM pada awal penjualan setiap harinya } \\
\text { Baris } 1 \text { entry manual khusus bulan Januari, sedangkan untuk bulan Februari sampai Desember } \\
\text { adalah otomatis dari baris akhir kolom stok akhir bulan sebelumnya } \\
\text { Baris } 2 \text { hingga akhir otomatis } \\
\text { Contoh: } \\
\text { Baris } 2 \text { Kolom Stok Awal = Baris } 1 \text { Kolom Stok Akhir }\end{array}$ \\
\hline Penerimaan & $\begin{array}{l}\text { Penerimaan BBM dari Depot Pertamina yang diterima } \\
\text { Baris } 1 \text { hingga akhir entry manual }\end{array}$ \\
\hline Total Stok & $\begin{array}{l}\text { Jumlah stok BBM awal + penerimaan setiap harinya } \\
\text { Baris } 1 \text { hingga akhir otomatis } \\
\text { Contoh: } \\
\text { Baris } 1 \text { Kolom Total Stok = Baris } 1 \text { Kolom Stok Awal + Baris } 1 \text { Kolom Penerimaan }\end{array}$ \\
\hline Penjualan & $\begin{array}{l}\text { Penjualan BBM setiap harinya } \\
\text { Baris } 1 \text { hingga akhir entry manual }\end{array}$ \\
\hline Stok Akhir & $\begin{array}{l}\text { Jumlah stok di akhir penjualan setiap harinya } \\
\text { Baris } 1 \text { hingga akhir otomatis } \\
\text { Contoh: } \\
\text { Baris } 1 \text { Kolom Stok Akhir = Baris } 1 \text { Kolom Stok Awal + Kolom Penerimaan - Kolom Penjualan }\end{array}$ \\
\hline
\end{tabular}

Format isian bulanan dibuat dengan input data series per hari sehingga dapat memenuhi kebutuhan informasi laporan harian. Rekapitulasi harian yang dilakukan melalui pemasukan data setiap harinya 
berdasarkan tanggal transaksi, selanjutnya disampaikan kepada PT (Persero) Pertamina melalui daring http://s.id/stokharian yang meliputi stok awal harian dan penjualan satu hari sebelumnya. Tabel turunan dalam worksheet bulanan adalah rekapitulasi bulanan pendistribusian BBM bersubsidi yang dibuat menggunakan fungsi tautan (link) dari tabel data bulanan dengan data series per hari. Uraian format rekapitulasi bulanan pada worksheet bulanan disajikan pada Tabel 2 .

Tabel 2. Uraian format rekapitulasi bulanan pada worksheet bulanan dilengkapi judul laporan bulanan per tanggal akhir bulan berjalan untuk rekapitulasi selama bulan berjalan

\begin{tabular}{lll}
\hline Komponen Data & \multicolumn{1}{c}{ Deskripsi } & \multicolumn{1}{c}{ Sumber Data } \\
\hline Stok (Awal) & $\begin{array}{l}\text { Stok awal BBM per tanggal akhir bulan sebelumnya, } \\
\text { sama dengan stok awal sebelum transaksi penjualan } \\
\text { pada tanggal awal bulan berjalan }\end{array}$ & Baris pertama kolom stok awal \\
Penerimaan & $\begin{array}{l}\text { Penerimaan per tanggal akhir bulan berjalan, yaitu } \\
\text { penerimaan BBM selama bulan berjalan }\end{array}$ & $\begin{array}{l}\text { Baris total tutup buku jumlah } \\
\text { penerimaan pada kolom penerimaan }\end{array}$ \\
Penjualan & $\begin{array}{l}\text { Penjualan per tanggal akhir bulan berjalan, yaitu } \\
\text { penjualan BBM selama bulan berjalan }\end{array}$ & $\begin{array}{l}\text { Baris total tutup buku jumlah penjualan } \\
\text { pada kolom penjualan }\end{array}$ \\
& $\begin{array}{l}\text { Stok akhir per tanggal akhir bulan berjalan, yaitu } \\
\text { stok akhir BBM setelah transaksi penjualan pada } \\
\text { Stok (Akhir bulan berjalan }\end{array}$ & $\begin{array}{l}\text { Stok awal ditambah jumlah penerimaan } \\
\text { dikurang jumlah penjualan }\end{array}$ \\
& & \\
\hline
\end{tabular}

Setelah proses tutup buku bulanan maka data harian otomatis masuk ke format rekapitulasi bulanan dan dapat digunakan untuk pelaporan karena telah memenuhi kebutuhan informasi laporan bulanan yang meliputi kondisi stok awal, jumlah penerimaan, jumlah penjualan dan kondisi stok akhir. Rekapitulasi bulanan, selanjutnya disampaikan kepada PT (Persero) Pertamina melalui daring http://s.id/stokbulanan. Rekapitulasi harian pendistribusian BBM bersubsidi pada SPBU-N Koperasi Perikanan Pantai Madani menggunakan format isian berbasis komputer ini diakumulasikan secara otomatis dalam worksheet tahunan (Tabel 3).

Tabel 3. Uraian rekapitulasi tahunan pada worksheet tahunan dilengkapi baris akhir tutup buku tahunan untuk rincian rekapitulasi selama satu tahun

\begin{tabular}{|c|c|c|}
\hline Komponen Data & Deskripsi & Sumber Data \\
\hline \multicolumn{3}{|c|}{ A. Komponen Rincian Rekapitulasi Bulanan } \\
\hline No & No urut sesuai bulan, include & \\
\hline Bulan & Bulan pencatatan selama 12 bulan, include & \\
\hline Stok Awal & Stok BBM pada awal bulan & $\begin{array}{l}\text { Stok awal pada rekapitulasi bulanan } \\
\text { sesuai bulan }\end{array}$ \\
\hline Penerimaan & Penerimaan selama periode bulanan & $\begin{array}{l}\text { Jumlah penerimaan pada rekapitulasi } \\
\text { bulanan sesuai bulan }\end{array}$ \\
\hline Penjualan & Penjualan selama periode bulanan & $\begin{array}{l}\text { Jumlah penjualan pada rekapitulasi } \\
\text { bulanan sesuai bulan }\end{array}$ \\
\hline Stok Akhir & Stok pada akhir bulan & $\begin{array}{l}\text { Stok akhir pada rekapitulasi bulanan } \\
\text { sesuai bulan }\end{array}$ \\
\hline \multicolumn{3}{|c|}{ B. Komponen Rekapitulasi Tahunan } \\
\hline Stok (Awal) & Stok BBM pada awal tahun & Baris tutup buku kolom stok awal \\
\hline Penerimaan & Penerimaan selama periode tahun berjalan & Baris tutup buku kolom penerimaan \\
\hline Penjualan & Penjualan selama periode tahun berjalan & Baris tutup buku kolom penjualan \\
\hline Stok (Akhir) & Stok BBM pada akhir tahun & Baris tutup buku kolom stok akhir \\
\hline
\end{tabular}

Tabel data dalam worksheet tahunan merupakan tabel turunan dari tabel data pada 12 worksheet bulanan yang memiliki relasi data menggunakan fungsi tautan (link) dan tersaji secara otomatis. Dalam worksheet 
tahunan, informasi rekapitulasi data terbagi dalam 2 (dua) bentuk, yaitu (1) rekapitulasi per bulan selama 12 bulan pada tahun berjalan, dan (2) rekapitulasi tahunan pada tahun berjalan. Rekapitulasi selama 12 bulan dibuat untuk memenuhi kebutuhan informasi pelaporan pendistribusian BBM bersubsidi yang akan disampaikan tertulis secara resmi kepada Badan Pemeriksa Keuangan Republik Indonesia (BPK RI) setiap tahunnya sehingga pihak SPBU-N hanya melakukan salin ulang rekapitulasi tersebut dalam format yang telah diedarkan oleh institusi tersebut. Sedangkan rekapitulasi tahunan dibuat untuk memenuhi kebutuhan informasi pelaporan tahunan yang disampaikan kepada PT (Persero) Pertamina melalui daring http://s.id/stoktahunan.

Proses tutup buku tahun berjalan dilakukan untuk memperoleh output data yang dibutuhkan untuk menyusun rekapitulasi tahunan kumulatif. Fungsi tautan pada output tutup buku tahunan digunakan untuk memperoleh output stok awal pada kolom "Stok Awal" dan output stok akhir pada kolom "Stok Akhir". Fungsi SUM digunakan untuk memperoleh output data jumlah penerimaan dan output data jumlah penjualan selama tahun berjalan. Sumber data output stok awal adalah sel data awal bulan kolom "Stok Awal" sedangkan sumber data output stok akhir adalah sel data akhir bulan kolom "Stok Akhir". Sumber data jumlah penerimaan adalah sel data awal hingga akhir bulan kolom "Penerimaan" tahun berjalan dan sumber data jumlah penjualan adalah sel data awal hingga akhir bulan kolom "Penjualan" tahun berjalan.

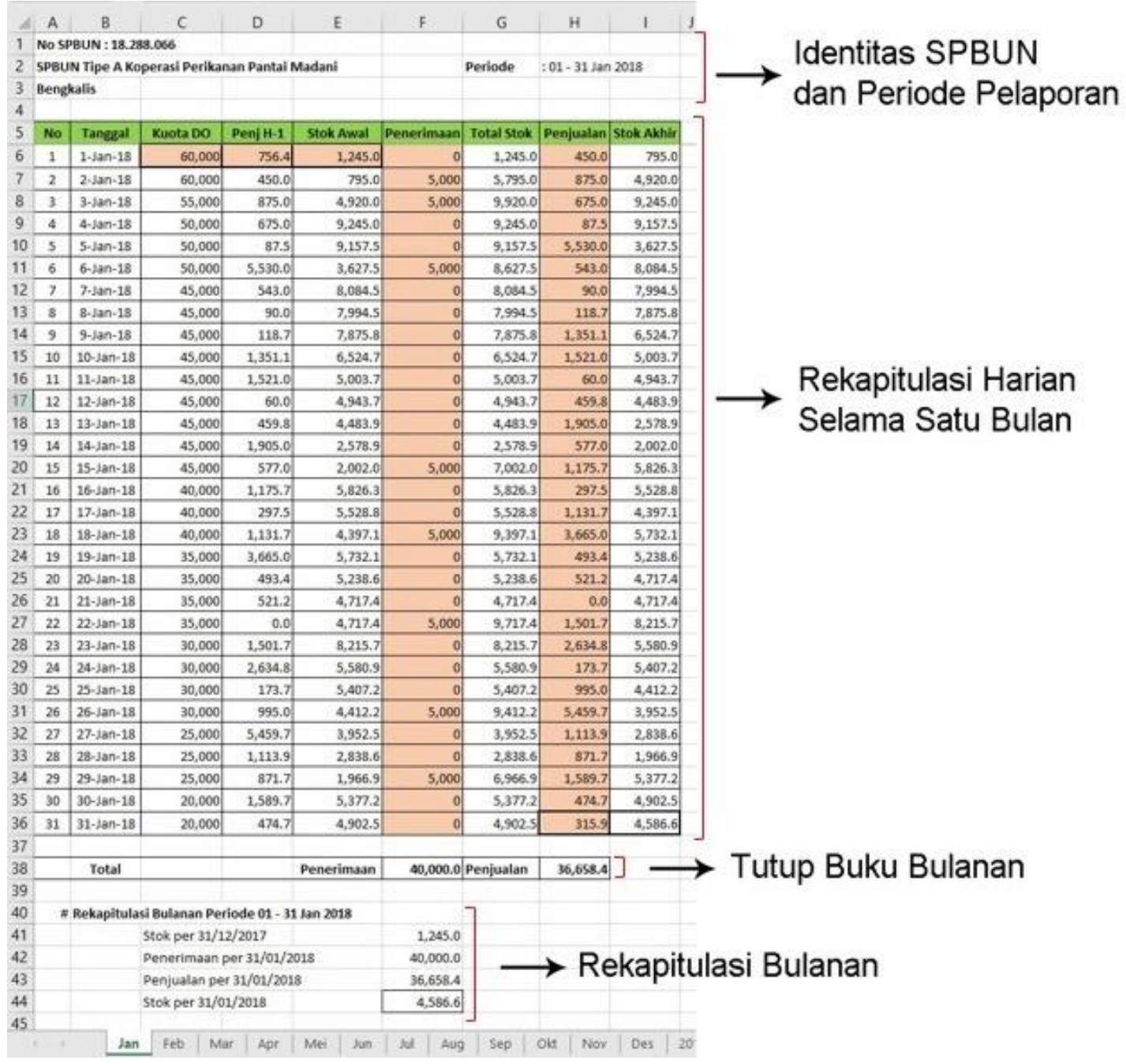

Gambar 2. Tampilan format isian worksheet bulanan

Tabel data pada worksheet bulanan dan tahunan disusun secara urut sesuai dengan proses terjadinya sehingga dapat diketahui perkembangan pendistribusian BBM bersubsidi dari jumlah persediaan, proses penjualan dan kondisi stok akhir. Penyusunan tabel data dalam format isian tersebut memperlihatkan tabel input dan tabel output. Tabel input membutuhkan entry data manual sedangkan tabel output akan tampil secara otomatis. Tampilan tabel data secara keseluruhan diupayakan untuk tidak kompleks tetapi sesederhana mungkin. Djamaris (2017) menyatakan bahwa penyusunan data yang baik akan memudahkan proses 
pengolahannya dimana tabel input dan tabel output bersifat spesifik sesuai kebutuhan sehingga suatu data dapat disusun dalam sebuah tabel yang sekaligus menjadi tabel input dan tabel output.

Tampilan format isian pendistribusian BBM bersubsidi berbasis komputer dijelaskan dalam bentuk contoh kasus. Untuk penjelasan ini maka contoh kasus adalah format isian dalam format Microsoft Office Excel 2007 untuk Tahun 2018. Contoh tampilan format disajikan dalam dua bentuk yaitu format tampilan worksheet bulanan dan tampilan worksheet tahunan. Untuk tampilan worksheet bulanan dengan contoh kasus bulan Januari 2018, disajikan pada Gambar 2.

Bentuk tampilan rekapitulasi bulanan dengan entry data series per hari (Gambar 2) dimulai pencatatannya dari tanggal 1 hingga 31 Januari 2018. Pemasukan data harian bersumber dari data rekapitulasi seluruh konsumen SPBU-N setiap harinya. Kolom dan baris yang diarsir menunjukkan entry data manual sedangkan kolom dan baris lainnya yang tidak diarsir adalah otomatis. Untuk bulan Januari setiap tahunnya, entry data manual, meliputi: (1) baris 1 kolom "Kuota DO", (2) baris 1 kolom "Penj H-1", (3) baris 1 kolom "Stok Awal", (4) kolom "Penerimaan", dan (5) kolom "Penjualan". Sedangkan untuk bulan Februari hingga Desember setiap tahunnya, pemasukan data manual, meliputi: (1) baris 1 kolom "Kuota DO", (2) kolom "Penerimaan", dan (3) kolom "Penjualan". Hal ini karena baris 1 kolom "Penj H-1" telah terhubung secara otomatis dengan baris terakhir kolom "Penjualan" pada bulan sebelumnya dan baris 1 kolom "Stok Awal" telah tertaut secara otomatis dengan baris terakhir kolom "Stok Akhir" pada bulan sebelumnya.

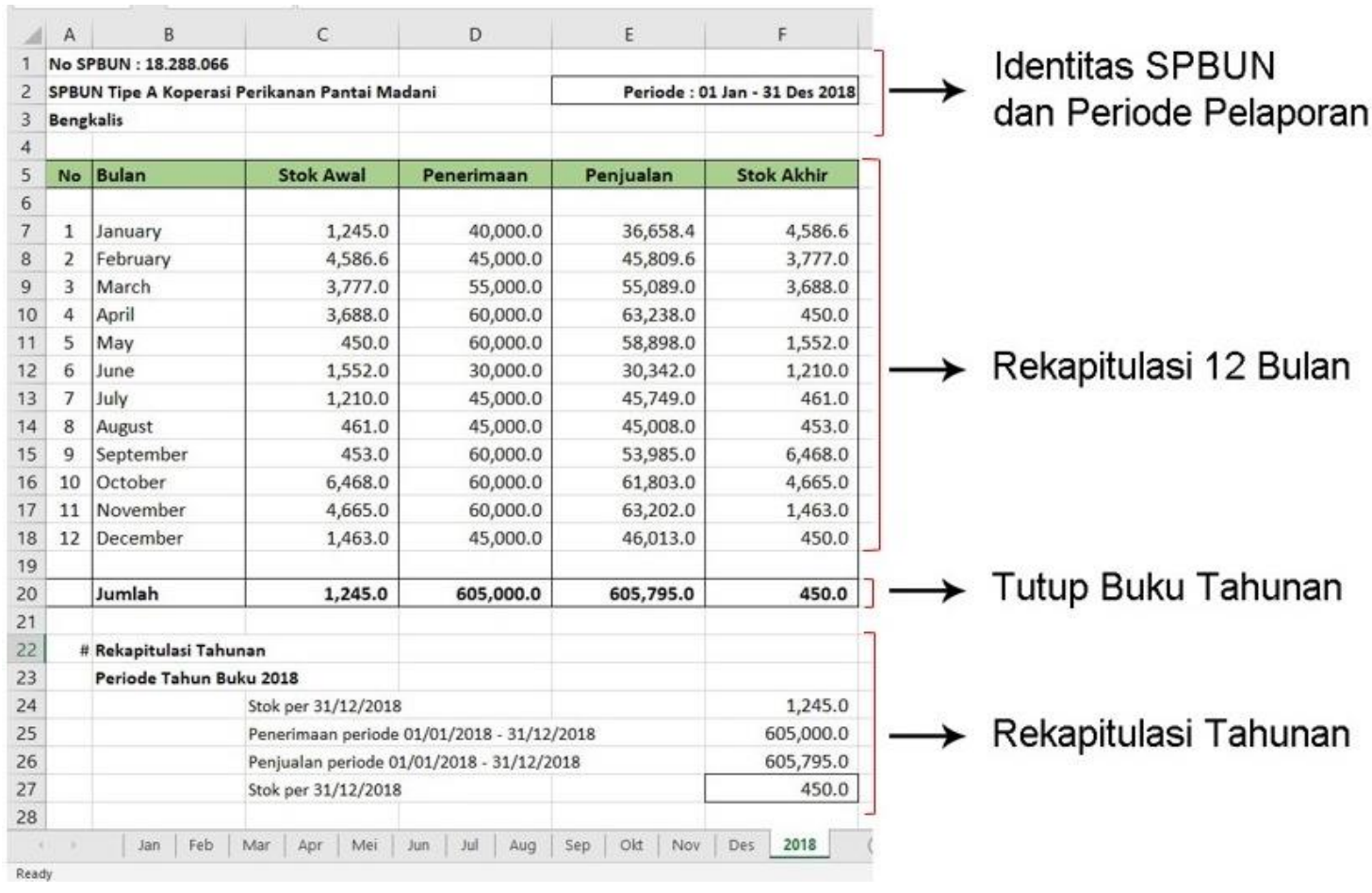

Gambar 3. Tampilan format isian worksheet tahunan

Rekapitulasi harian pada kolom "Stok Awal" dan kolom "Penj H-1" diteruskan oleh tenaga administrasi koperasi menjadi laporan stok harian SPBU-N kepada PT (Persero) Pertamina melalui daring http://s.id/stokharian. Proses tutup buku setiap bulan dilakukan untuk mengakhiri pencatatan pada bulan berjalan. Proses ini dilakukan dengan cara menjumlahkan seluruh persediaan pada kolom persediaan dan seluruh penjualan pada kolom penjualan selama bulan berjalan. Teknik penjumlahan ini menggunakan fungsi formula SUM terhadap RANGE data awal hingga akhir bulan pada kolom dimaksud. Dalam penggunaan Microsoft Excel selalu berhubungan dengan CELL dan RANGE yang didefinisikan bahwa CELL adalah perpotongan antara kolom dengan baris sedangkan RANGE adalah gabungan dari beberapa CELL sehingga fungsi formula SUM dapat digunakan terhadap RANGE suatu kumpulan data (Cholid, 2008). Rekapitulasi bulanan yang telah tertaut secara otomatis dengan rekapitulasi harian terdiri dari kondisi stok awal, penerimaan, penjualan dan stok akhir. Komponen rekapitulasi ini digunakan sebagai laporan stok bulanan SPBU-N yang disampaikan tenaga administrasi koperasi kepada PT (Persero) Pertamina melalui daring http://s.id/stokbulanan pada setiap awal bulan berikutnya. 
Seluruh rekapitulasi bulanan dalam worksheet bulanan akan ditautkan dalam format worksheet tahunan sesuai urutan bulan sehingga diperoleh output secara otomatis. Tampilan format worksheet tahunan dengan contoh kasus Tahun 2018, disajikan pada Gambar 3.

Tampilan worksheet tahunan terdiri dari tampilan rekapitulasi selama 12 bulan dan tampilan rekapitulasi kumulatif selama tahun 2018. Rekapitulasi selama 12 bulan tersebut disalin ulang tenaga administrasi koperasi kedalam format edaran BPK RI dan disampaikan sebagai laporan tertulis secara resmi pendistribusian BBM bersubsidi selama tahun 2018. Sedangkan rekapitulasi tahunan kumulatif disampaikan kepada PT (Persero) Pertamina melalui daring http://s.id/stoktahunan pada awal tahun 2019. Penyampaian laporan pada halaman resmi di website yang dikembangkan PT (Persero) Pertamina adalah untuk transparansi pendistribusian BBM bersubsidi, memperkecil resiko penyelewengan pendistribusian dan tepat sasaran. Format isian berbasis komputer ini dibuat dalam upaya mendukung SPBU-N Koperasi Perikanan Pantai Madani untuk memenuhi kebutuhan data pelaporan tersebut. Menurut Carwoto (2009), mekanisme penyaluran bahan bakar minyak (BBM) secara transparan, mampu telusur, serta memiliki resiko yang kecil dari kemungkinan penyelewengan atau penyalahgunaan sangat diperlukan bagi sistem penyaluran BBM bersubsidi dengan alternatif solusi adalah menerapkan teknik otomasi pengendalian proses distribusi menggunakan platform teknologi informatika dan komputer.

Khususnya penyaluran BBM bersubsidi bagi nelayan melalui SPBU-N, pemantauan dan pengawasan sangat penting dilakukan. Suryawati dan Apriliani (2015) menyatakan bahwa operasional pendistribusian BBM bersubsidi perlu diawasi agar lebih tepat sasaran sesuai dengan skala usaha penangkapan.

\section{Keunggulan}

Keunggulan dari format isian berbasis komputer ini, yaitu: (1) efektif dalam mendapatkan output informasi yang tepat dan akurat; (2) efisien karena entry data yang dilakukan hanya jumlah penjualan dan penerimaan harian; dan (3) tenaga administrasi koperasi dapat memberikan koreksi atas kesalahan hitung yang dilakukan oleh manajer. Kelemahan dari penggunaan format ini adalah input data masih dilakukan secara manual yang bersumber dari data berbasis pesan singkat telepon seluler.

\section{Penerapan}

Implementasi format isian berbasis komputer dengan memanfaatkan aplikasi Microsoft Office Excel 2007 sangat mudah diterapkan untuk SPBU-N karena adanya fasilitas komputer dan tenaga administrasi yang memiliki kemampuan menggunakan aplikasi Microsoft Office Excel 2007. Pihak SPBU-N Koperasi Perikanan Pantai Madani telah menggunakan format ini untuk pencatatan pendistribusian BBM bersubsidi untuk tahun 2019. Penyediaan format kosong untuk tahun 2019 dilakukan dengan cara menyimpan file isian tahun 2018 menjadi sebuah file format isian tahun 2019. Kemudian menghapus data pada baris entry manual pada setiap worksheet dan mengganti periode tanggal di setiap worksheet menjadi periode pencatatan tahun 2019.

\section{KESIMPULAN}

Kegiatan ini telah mencapai target dengan tersedianya format isian berbasis komputer untuk pendistribusian BBM bersubsidi di SPBU-N Koperasi Perikanan Pantai Madani. Penyediaan format isian berbasis komputer dan peningkatan kapasitas tenaga administrasi koperasi telah membantu SPBU-N dalam menyediakan informasi yang akurat untuk disampaikan kepada PT (Persero) Pertamina dalam bentuk laporan harian, bulanan dan tahunan. Kegiatan ini telah memberi dampak positif kepada SPBU-N dalam memantau perkembangan pendistribusian BBM bersubsidi untuk nelayan. Rekomendasi untuk kegiatan pengabdian masyarakat berikutnya adalah penguatan Koperasi Perikanan Pantai Madani untuk mengimplementasikan sistem berbasis komputer pada SPBU-N secara baik dan benar dalam memantau perkembangan pendistribusian BBM bersubsidi untuk nelayan.

\section{UCAPAN TERIMA KASIH}

Penulis mengucapkan terima kasih kepada pengelola SPBU-N, pengurus, pengawas dan anggota Koperasi Perikanan Pantai Madani yang turut serta membantu selama kegiatan ini dilakukan.

\section{DAFTAR PUSTAKA}

Cholid, C. 2008. Modul Microsoft Excel. Jakarta: Pusdiklat Departemen Pendidikan Nasional. 
Djamaris, A. R. A. 2017. Analisis Data Menggunakan Microsoft Excel. Fakultas Ekonomi dan Ilmu Sosial. Jakarta: Universitas Bakrie.

Hidayat, W., Tambunan T.D. dan Yuningsih. 2017. Penggunaan Spreadsheet Apps untuk Pengolahan Data Menjadi Laporan. Bandung: Fakultas Ilmu Terapan. Universitas Telkom.

Kementerian Kelautan dan Perikanan (KKP). 2015. Peraturan Menteri Kelautan dan Perikanan Nomor 13/PERMENKP/2015 tentang Petunjuk Pelaksanaan Penerbitan Surat Rekomendasi Pembelian Jenis Bahan Bakar Minyak Tertentu untuk Usaha Perikanan Tangkap. Jakarta: Kementerian Kelautan dan Perikanan.

Koperasi Perikanan Pantai Madani (KPPM). 2013. Laporan Tahunan 2012. Bengkalis: Koperasi Perikanan Pantai Madani.

Koperasi Perikanan Pantai Madani (KPPM). 2015. Laporan Tahunan 2014. Bengkalis: Koperasi Perikanan Pantai Madani.

Koperasi Perikanan Pantai Madani (KPPM). 2018. Laporan Tahunan 2017. Bengkalis: Koperasi Perikanan Pantai Madani.

Sumardi, Y. 2002. Penggunaan Microsoft Excel dalam Analisis Data Eksperimen pada Pembelajaran Fisika. Jurnal Cakrawala Pendidikan 21(2) : 196-212.

Suryawati, S.H. dan Apriliani, T. 2015. Mekanisme Penyaluran Bahan Bakar Minyak Bersubsidi pada Usaha Perikanan Tangkap Skala Kecil. Jurnal Kebijakan Sosial Ekonomi Kelautan dan Perikanan 5(1) : 37-46.

Yayasan Laksana Samudera [YLS]. 2003. Laporan Pendampingan Teknis Koperasi Perikanan Pantai Madani Penerima Dana Modal Awal dan Padanan (MAP). Pekanbaru: Yayasan Laksana Samudera. 